\title{
The Impact of Indonesian Government Policies in Facing the Covid-19 Pandemic
}

\author{
Mhd. Ansori*, Nuraini \\ Faculty of Law \\ Batanghari University, UNBARI \\ Jambi, Indonesia \\ *mhd.ansori@unbari.ac.id
}

\begin{abstract}
In this study the question is the impact of the Indonesian Government's policies in facing the Covid-19 Pandemic because various policies have been carried out by the Indonesian Government. Government policies that limit working hours lead to layoffs resulting in increased unemployment with high criminal effects, many employers ask the Government to open lockdowns because they are unable to survive for a long time. In the field of education, the learning material obtained by students is not optimal, besides the signal constraints in several regions in Indonesia. Various public services change which makes people feel constrained, especially services in the health sector. This study aims to analyze the impact of the Indonesian Government's policies in facing the Covid-19 Pandemic. This research was conducted with a qualitative approach through normative legal methods. The Indonesian Government's policies to deal with the Covid-19 Pandemic not only hampered the community in various aspects of life, some also helped the community such as banking policies that helped customer credit, wage subsidies, electricity subsidies, quota subsidies, assistance for micro, smal and medium enterprises, income assistance to each head of family of course this is with certain terms and conditions, the various policies have several obstacles in their implementation. The impact of the Indonesian Government's policies in dealing with the Covid-19 Pandemic is very diverse, but this has really helped Indonesians face the Covid-19 Pandemic.
\end{abstract}

Keywords—impact, policy, government, pandemic

\section{INTRODUCTION}

Indeed, in 2020 this is a year of crisis and worry experienced by all countries in the world due to the Covid-19 virus pandemic [1]. The first case of Covid-19 began with pneumonia in Wuhan City, Hubei Province, China on December 31, 2019 [2].

Meanwhile, the first case of Covid-19 in Indonesia was confirmed on March 2, 2020 with 2 (two) positive patients, until now the number of confirmed positive cases continues to grow, recorded until December 5, a total of 569,707 people, who were declared cured as many as 470,449 people and who died as many as 17,589 people while for the number of specs as many as 69,926 and the number of specimens 54,922 [3].
To overcome the spread of the virus, there are currently 3 (three) government policies related to tackling covid-19, based on a collaboration model that involves all experts from health, economy, religion, resilience and others seeks to formulate strategic policies, 3 (three) policies include: (The replacement government regulation law) Number 1 Year 2020 (Government Regulation) Number 21 of 2020, Presidential Decree No. 11 of 2020 [4]. In addition, the government has carried out several policies, among others, such as establishing the Covid-19 virus outbreak as a national disaster through The Presidential Decree No. 2 of 2020 on The Determination of Non-Natural Disasters of the Spread of Corona Virus Disease 2019 as a national disaster. The government also implemented Large-Scale Social Restrictions for areas included in the red zone through The Minister of Health Regulation No. 9 of 2020 on Guidelines for Large-Scale Social Restrictions [5].

After that, the Indonesian government also took steps including by enforcing online learning, imposing Large-Scale Social Restrictions, working from home and providing social assistance. This social assistance policy is channeled through the Ministry of Social Affairs of the Republic of Indonesia and there are also various social assistance programs issued by the Central and Local Governments. The social assistance is the Family of Hope Program by the Ministry of Social Affairs, Non-Cash Food Assistance /groceries by the Ministry of Social Affairs, Food Social Assistance / groceries by the Ministry of Social Affairs, Cash Social Assistance distributed through the POS by the Ministry of Social Affairs, Cash Social Assistance distributed through HIMBARA (Association of State-Owned Banks) by the Ministry of Social Affairs, Direct Cash Assistance of Village Funds by the Ministry of Villages, Micro Small and Medium Enterprises Assistance by the Ministry of Small and Medium Enterprises cooperatives, Employee Salary Subsidies and Pre-Employment Programs by the Ministry of Manpower, and various kinds of Cash and Sembako Social Assistance whose sources of funds are from the Regional Budget in each province / district / city, which may vary from regions to each other, electricity subsidies, bank loan relief and so on [6].

Looking at the problems of social assistance that occurred to date both in the Central Government and in the Region there was criticism from both the public and officials, as conveyed by Ridwan Kamil as the Governor of West Java, he said that 
each ministry has its own data survey that results in data owned by the Central Government and Local Government is not in sync. This data resulted in the rejection of social assistance in the West Java provincial government by a number of village heads in Sukabumi Regency, because there was no valid data and overlap with the data of citizens who were registered as recipients of the Family of Hope Program from the Central Government [7]. On Saturday, December 5, 2020 the Corruption Eradication Commission secured three suspects of corruption of the Social assistance Package, one of whom was JPB (Minister of Social Affairs) [8].

\section{RESEARCH METHODOLOGY}

This study aims to analyze the impact of the Indonesian Government's policies in facing the Covid-19 Pandemic. This research was conducted with a qualitative approach through normative legal methods.

\section{RESULTS AND DISCUSSION}

The Covid-19 pandemic has caused casualties for the people of Indonesia. Since President Joko Widodo announced on March 2, 2020, from time to time the number of victims exposed to Covid-19 has increased, increasingly endangering and threatening public health, this has an impact not only on public health, but also affects sectors that are other. It is proven that the Covid-19 pandemic has had an impact, among others, on a slowdown in national economic growth, a decrease in state revenues, and an increase in state spending and financing. For this reason, government efforts are needed to save health and the national economy, with a focus on spending on health, social safety nets, and economic recovery, including for the business world and the affected communities [9].

In addition, the Covid-19 pandemic has had a systemic and multidimensional impact on almost all aspects of life. The most prominent impacts apart from health impacts are economic and social impacts [10].

In the world of education, the impact of the post-Covid-19 pandemic entered Indonesia which then in mid-March 2020 to reduce the number of Covid 19 sufferers, the provincial and local governments produced policies in the world of education, namely temporarily eliminating face-to-face learning and replaced with online learning at both the school and college levels high, manifested in a system called an electronic university (e-University). The development of e-University aims to support the implementation of education, so that universities can provide better information services to their communities, both inside and outside the tertiary institutions via the internet [11].

It is a heavy duty for the President to improve the welfare of his people, in the dictionary of State Administration Law it is known as "bestuurszorg", namely the task of the government to organize public welfare [9].

In realizing the people's welfare, government officials are given the freedom to act to solve the concrete problems faced in the administration of government. This is known as freies ermessen or discretion. Freies Ermessen or discretion is owned by every office holder or government official to take strategic policies in the form of decisions or actions in overcoming urgent concrete problems that require immediate handling. The policies of government officials that are implemented in the form of discretion are protected by a legal umbrella, so that every government official who acts on behalf of his position and is used for the public interest will get legal protection [9].

Sjachran Basah, as quoted by Ridwan HR, argues that the freies ermessen (discretion) given to the government or state administration is a logical consequence of the conception of the welfare state, but within the framework of the legal state freies ermessen cannot be used indefinitely. On that basis Sjachran Basah put forward the elements of Freies Ermessen in a constitutional state, namely [12]:

- Intended for performing public service duties.

- Is an active act of the state administration.

- This attitude of action is made possible by law.

- The attitude of the action was taken on his own initiative.

- This attitude of action is intended to solve important problems that arise suddenly.

- Such attitudes can be accounted for both morally to God Almighty and legally.

Then based on Article 34 of the 1945 Constitution of the Republic of Indonesia the State / Government is given responsibility for the implementation of social welfare for its people, this can be seen in the provisions of Article 34 of the 1945 Constitution of the Republic of Indonesia as follows: (1) Fakir poor and neglected children are cared for by the state. (2) The state develops a social security system for all the people and empowers the weak and underprivileged people according to human dignity. (3) The state is responsible for the provision of adequate health service facilities and public service facilities. (4) Further provisions regarding the implementation of this article are regulated in law.

This requires community participation, as stated by John Locke and Stuart Mill that the involvement of citizens in the public policy process is very important because it is able to provide knowledge and understanding and develop a sense of social responsibility [13]. In essence, policies are decisions or action choices that directly regulate the management and distribution of natural, financial and human resources in the public interest [14]. An explanation of public policy (public policy) was also put forward by William N. Dunn, which according to him the complex dependence pattern of interdependent collective choices, includes decisions not to take an action made by government agencies or offices [15].

There are not a few experts who provide opinions on public policy, of the many opinions, when examined, most of the expert's link public policy with a government decision or 
decision to take an action that is considered to have a better impact with the aim that people's lives will also be better good [16].

The understanding of several experts raises several implications that public policy must:

- Always have a specific goal or at least be a goaloriented action;

- Contains actions or patterns of actions taken by government officials;

- Regulate what the government actually does;

- Positive in nature, which means that there are several forms of government action that contain a particular problem or have a negative character in the sense that it is the government's decision not to do something;

- Based on statutory regulations that are compelling (authoritative) [16].

Public policy has the aim of being a set of government actions designed to produce certain things that will ultimately satisfy the public because it is in accordance with their expectations because the public is a constituent of the government. Therefore, public policy is considered a legal and legitimate choice of action because it is made by institutions that have legitimacy in the government system [16].

This is in line with what was stated by Dye, "public policy is whatever governments choose to do or not to do" [17], which translates to public policy as everything the government chooses to do or not do something [18].

After the positive cases of Covid 19 increased, several government policies began to be changed, namely:

- Providing free personal protective equipment (PPE) for covid 19 referral hospitals;

- Buy a covid 19 test kit;

- Appealing to the public not to leave the area;

- Appealing to the public to carry out social distancing, physical distancing, diligently wash their hands using soap, and campaign for the slogan "at home";

- Create a policy to close schools and universities, as well as a work from home policy;

- Conducting rapid covid 19 tests, spraying disinfectants in public places;

- Check the health of people who travel outside the area and even isolate;

- Taking various economic policies to maintain people's purchasing power;

- Implementing Large-Scale Social Restrictions (PSBB) policies [19].
Finance Minister Sri Mulyani stated that the social protection budget in the context of handling the Covid-19 pandemic had absorbed IDR 170.2 trillion or $69.6 \%$ of the total budget of IDR 244.59 trillion. The social protection budget itself consists of the Family Hope Program, Basic Food Cards, Jabodetabek Social Assistance, Social Assistance for Outside Jabodetabek, Pre-Employment, Electricity Discounts, Salary Subsidies, Education Quota / Internet Subsidy, and Teacher Honorary Salary Assistance [20].

In general, social assistance in the form of direct cash assistance can help ease the household economy during a pandemic, where people are encouraged to stay at home. Economically, this program has helped the community's economy in increasing purchasing power, on the one hand, the provision of Direct Cash Assistance from a social point of view has caused turmoil in the form of conflict, the cause is that the distribution in several places was not carried out properly, fairly and wisely, resulting in turmoil in middle of society [10].

According to Article 1 number 15 Regulation of the Minister of Home Affairs Number 32 of 2011 concerning Guidelines for Grants and Social Assistance, social assistance is the provision of assistance in the form of money / goods from local governments to individuals, families, groups and / or communities that are not continuous and selective which aims to protect from possible social risks.

This is very likely to be done by the government because there is an opportunity for the budget as a bailout input in increasing the power to handle economic externalities during this pandemic. The opportunity referred to is that normatively the government has issued 9 (nine) legal products related to the handling of Covid-19, namely 4 (four) Presidential Decrees (Keppres), 2 (two) Presidential Regulations (Perpres), 1 (one) Government Regulation (PP), 1 (one) Presidential Instruction (Inpres), and 1 (one) Government Regulation in Lieu of Law (Perppu). The entire regulation is a response to escalating problems, both in terms of health, bureaucracy, politics, and state finances in handling Covid-19 [21]

Unfortunately, this government regulation in lieu of Law No.1 of 2020 concerning State Financial Policy and Financial Stability for Handling Covid-19 actually touches the realm of the education endowment fund, while the supra-government project through the "new capital" project is not touched in this regulation, even though The nature of the project has a qualified option to be canceled, through a government regulation in lieu of this law, the education endowment fund has become a victim, even though education policy is a domain that should not be disturbed when other sectors are still allowed to be postponed, besides that, the project Local government projects through the Special Allocation Fund (DAK) scheme, General Allocation Fund (DAU), and Profit Sharing Funds originating from the State Revenue and Expenditure Budget are also affected, as a result development in the regions is halted because of three sources of the Revenue Budget and The regional expenditure has been deducted accordingly the conditions of each region, whereas the budget formulation of 
one mega project in the new capital has equality in saving various developments in the regions through these three components of budget sources [22].

In addition, the legal product of the regional quarantine policy in Law number 6 of 2018 concerning Health Quarantine, in article 9 states that quarantine is carried out with the aim of protecting the community from disease and / or other causes of public health risks. In the quarantine policy, the Central Government and Local Governments will ensure that the community remains healthy and is responsible for meeting community needs. Lockdown and social distancing policies can be the right solution to deal with the Covid 19 virus [23]. Because this policy is able to minimize the spread of the covid 19 virus [24]. However, in fact not all have the same perceptions and reasoning in seeing the policies for handling covid in Indonesia, so some people obey and many do not [19].

In terms of handling Covid 19 from the government's side, weak coordination and confusion in communication have further undermined public confidence in the government in dealing with this invisible enemy [19].

The Indonesian government has issued several policies. Among them are the policy of dismissing schools, universities, working from home, worshiping from home, conducting mass rapid tests, providing social assistance, issuing appeals for social distancing and physical distancing, and implementing large-scale social restrictions (PSBB). This shows that the policies taken by the government show rational reasoning. It can be seen that the success of the policy is determined by the public response to the policy. In terms of handling Covid-19 in Indonesia, state policies with rational reasoning will be able to be accepted rationally by the community if the Government also issues policies to ensure the availability of economic resources for the community [19].

\section{CONCLUSION}

The impact of the Indonesian Government's policies in facing the Covid-19 Pandemic is very diverse, felt by the community, various levels of society feel the impact so that there are pros and cons of a public policy carried out by the government, but this is ultimately enough to help Indonesian people face the economic and social impacts of the CovidPandemic 19.

\section{REFERENCES}

[1] L.T. Phan, T.V. Nguyen, Q.C. Luong, T.V. Nguyen, H.T. Nguyen, H.Q. Le, ... and Q.D. Pham, "Importation and human-to-human transmission of a novel coronavirus in Vietnam," New England Journal of Medicine, vol. 382 , no. (9), pp. 872-874, 2020 .

[2] K. Sulistiani and K. Kaslam, "Kebijakan Jogo Tonggo Pemerintah Provinsi Jawa Tengah dalam Penanganan Pandemi Covid-19," Vox Populi, vol. 3, no. (1), pp. 31-43, 2020

[3] A.E. Prawira, "COVID-19 di Indonesia 5 Desember, Kasus Positif Corona Bertambah 6.027," 2020. [Online]. Retrieved from: m.liputan6.com [Accessed on: 5 December 2020. 15;50 WIB].
[4] A.S. Cahyono, "Implementasi Model Collaborative Governance Dalam Penyelesaian Pandemi Covid-19," Jurnal Publiciana, vol. 13, no. (1), pp. 83-88, 2020.

[5] D. Arififn, "Presiden tetapkan COVID-19 Sebagai Bencana NasionalBNPB," [Online]. Retrieved from: BNPB website: https://bnpb.go.id/berita/presiden-tetapkan-covid19sebagaibencananasional [Accessed on: june 24, 2020].

[6] "Jenis-Jenis Bantuan Sosial dari pemerintah Selama Pandemi," [Online]. Retrieved from: www.PKH Pati.Com [Accessed on: Rabu, 2 September 2020].

[7] W. Rahmansyah, R.A. Qadri, R.R.A. Sakti, and S. Ikhsan, "Pemetaan Permasalahan Penyaluran Bantuan Sosial Untuk Penanganan Covid-19 Di Indonesia,” JURNAL PKN (Jurnal Pajak dan Keuangan Negara), vol. 2, no. (1), pp. 90-102, 2020.

[8] www.kpk.go.id/id/berita/siaran-pers/1985-kpk-gelar-tangkap-tanganterkait-perkara-dugaan-suap-pengadaan-Bantuansosial-covid-19 [Accessed on: 8 Desember 2020].

[9] H. Juliani, "Kebijakan Fiskal: Anggaran Belanja Negara Untuk Perlindungan Sosial Dalam Penanganan Pandemi Covid 19," Administrative Law and Governance Journal, vol. 3, no. (4), pp. 595 516, 2020.

[10] B. Iping, "Perlindungan sosial melalui kebijakan program Bantuan Langsung Tunai (BLT) di Era Pandemi Covid-19: Tinjauan perspektif ekonomi dan sosial," Jurnal Manajemen Pendidikan Dan Ilmu Sosial, vol. 1, no. (2), pp. 516-526, 2020.

[11] Y. Pujilestari, "Dampak Positif Pembelajaran Online Dalam Sistem Pendidikan Indonesia Pasca Pandemi Covid-19," 'ADALAH, vol. 4, no. (1), 2020.

[12] H.R. Ridwan, Hukum Administrasi Negara Edisi Revisi. Jakarta: Raja Grafindo Persada, 2013

[13] B. Winarno, Kebijakan Publik, Teori Proses dan Studi Kasus Yogyakarta : Caps., 2012.

[14] E. Suharto, Kebijakan Sosial Sebagai Kebijakan Publik. Bandung: Alfabeta, 2008.

[15] W.N. Dunn, Analisis Kebijakan Publik, Terjemahan. Yogyakarta: PT. Hanindita Graha Widya, 2003.

[16] P.S. Saraswati, "Kebijakan Hukum Terhadap Penanganan Pandem Covid-19 Di Indonesia," KERTHA WICAKSANA, vol. 14, no. (2), pp. 147-152, 2020.

[17] T.R. Dye, Understanding Public Policy. United States of America: Prentice-Hall, 1992

[18] S. Anggara, Kebijakan Publik. Bandung: CV Pustaka Setia, 2014.

[19] Z. Harirah and A. Rizaldi, "Merespon Nalar Kebijakan Negara Dalam Menangani Pandemi Covid 19 Di Indonesia," Jurnal Ekonomi dan Kebijakan Publik Indonesia, vol. 7, no. (1), 2020.

[20] https://m.cnnindonesia.com/ekonomi/20201110135802-532-568057/srimulyani-klaim-serapan-dana-perlindungan-sosial-70-persen

[21] A. Widianingrum and W. Mas'uid, Dinamika Respon Pemerintah Nasional: Krisis Kebijakan Penanganan Covid-19. Fakultas Ilmu Sosial dan Ilmu Politik UGM: UGM Press, 2020.

[22] H. Kurniawansyah, A. Amrullah, M. Salahuddin, M. Muslim, and S. Nurhidayati, "Konsep kebijakan strategis dalam menangani eksternalitas ekonomi dari COVID-19 pada masyarakat rentan di indonesia," Indonesian Journal of Social Sciences and Humanities, vol. 1, no. (2) pp. 130-139, 2020.

[23] M. Mukharom and H. Aravik, "Kebijakan Nabi Muhammad Saw Menangani Wabah Penyakit Menular dan Implementasinya dalam Konteks Penanggulangan Coronavirus Covid-19," SALAM: Jurnal Sosial dan Budaya Syar-i, vol. 7, no. (3), pp. 239-246, 2020.

[24] N.R. Yunus and A. Rezki, "Kebijakan Pemberlakuan Lockdown sebagai Antisipasi Penyebaran Corona Virus Covid 19," Salam: Jurnal Sosial \& Budaya Syar'I, vol. 7, no. (3), pp. 227- 238, 2020. 